Amtul Hafeez Gondal 123

\title{
Women's Involvement In Earning Activities: Evidence From Rural Pakistan
}

\section{Amtul Hafeez Gondal ${ }^{*}$}

\begin{abstract}
Based on the Pakistan Integrated Household Survey (PIHS) 1998-99 the paper highlights the factors that influence the decision of married women in their participation/economic activities in rural Pakistan. Employing the probit model on 9427 observations it is found that married women in Sindh and Punjab are more likely to engage in economic activities than their counterparts in Balochistan and NWFP. Women's age, family size and husbands working in agriculture have a significant positive effect on the involvement of rural women in economic activities. Household annual income, nuclear family system, number of children and husbands' literacy level and age have a strong negative effect. No significant relationships of education, migration status and the female being head of the household have been found.
\end{abstract}

\section{Introduction}

Like other developing countries' women in Pakistan make significant contributions in agriculture, household and other rural activities directly or indirectly. Despite recent increases in the proportion of working women the number of working women is still quite small. The main reason for the low involvement of women in economic activities is various socioeconomic constraints, which hinder women's participation in the labour market. Married women have several commitments at home. They have to look after their children and perform numerous household chores. Decision-making in Pakistan has been regarded as a predominantly male prerogative. Women are largely neglected in social, economic, political and legal spheres, although some progress has been made in the enhancement of women in all areas of society. Women labour force participation in Pakistan at $28 \%$ is ranked the lowest in the South Asian region. The share of women earning in earned

\footnotetext{
* The author is Doctoral Candidate of Economics, Quaid-e-Azam University, Islamabad and also visiting lecturer at Fatima Jinnah Women University, Rawalpindi. She is thankful to Dr. Eatzaz Ahmed, Professor and Chairman, Department of Economics, Quaid-e-Azam University, Islamabad for his guidance and valuable comments.
} 
income is $26 \%$ of male earnings while their economic activities rate, as a percentage of that of the male is $40 \%{ }^{1}$

Various studies have been carried out to analyse the labour force participation of women. Ibraz (1993) found that rural women are extensively involved in many agricultural and livestock rending operations, processing of dairy products, poultry and handicrafts. Besides these productive activities they also perform household chores. Jamil (2001) analysed the determinants of women labour force participation in Pakistan using the 1996-1971 Labour Force Survey. The study found that the effect of residence on women labour force participation in the urban areas is negative in all four provinces and in the overall analyses of Pakistan. Similarly, Chaudhry and Khan (1987) found that the activity rates of rural women depend to a large extent on the social status of the household concerned. Landlessness and land ownership are generally indicative of the poverty and richness respectively of a household. Household incomes are inversely related to women activities rates. Women participation rates fell as a result of increase in rural incomes. In recent years, the increased mechanisation of agriculture in Pakistan has also tended to contribute to a decline in rural women participation rates. In rural areas, women have remained involved in a variety of agricultural activities for a long time, such as land preparation, seed preparation, collecting farmyard manure, weeding and harvesting. Women also undertake the responsibility of cleaning, drying, and storage of grains. This increases their workload after the harvesting operations. Taking care of livestock is by and large the responsibility of women. They collect fodder, clean sheds and process animal products [Khan and Bilquees (1976); Ahmad, Asghar and Khan (1993); and Sarwar and Saleem (1993)].

The paper presents an empirical analysis of the involvement of rural women economic activities (hereafter IRWEA) using the nonlinear maximum likelihood probability (probit) function. ${ }^{2}$ The data is taken from the Pakistan Integrated Household Survey (PIHS) 1998-99.

Section 2 lays out the general model employed for analyses, data and construction of variables. Section 3 presents and analyses the probit estimates. Finally, section 4 consists of conclusion and policy implications.

\footnotetext{
${ }^{1}$ Bangladesh and India have 42 and 32\% respectively. South Asia's average is $33 \%$. For details see 'Human Development in South Asia 2000: The Gender Question'.

${ }^{2}$ The involvement of currently married women in earning/economic activities refers to all the currently married women who worked for at least one hour during the reference period and were either paid employed or self employed.
} 


\section{Methodology}

This research estimates the regression model in which IRWEA is a function of several explanatory variables. The dependent variable can take only two binary values: 1 if a woman participates in earning activities and 0 if she does not. The paper estimates the nonlinear miaximum likelihood function for the normal probability (probit) model.

It starts with a general function

$$
Y=f\left(X_{1}, \ldots, X_{n}\right)
$$

where $Y_{i}$ denotes IRWEA. $Y$ is equal to 1 if a woman participates in earning activities and equal to zero if she does not. $X_{1, \ldots,} X_{n}$ represent various socio-economic and demographic factors leading to women's decision to be involved in earning activities.

\section{Normal Probability (Probit) Model}

To explain the dichotomous dependent variable the probit model that emerges from the normal cumulative distribution function will be used. Suppose $\mathrm{y}^{*}$, the ability to participate in economic activities, is unobservable and it depends on a set of observed factors $X_{i}$. That is

$$
y_{i}^{*}=\beta X_{i}+\varepsilon_{i}
$$

where $\beta$ is a row vector of parameters, and $X_{i}$ is the column vector of the variables that affect $y^{*}$ and $\varepsilon i$ is normally distributed with 0 mean. The observable binary variable is related to $y^{*}$ in the following sense:

$$
\begin{aligned}
Y & =1 & & \text { if } y^{*}>0 \\
& =0 & & \text { otherwise }
\end{aligned}
$$

Given the normality assumption, the probability that $y^{*}$ is less than or equal to $Y$ can be computed from the standardised normal cumulative distribution function as:

$$
P_{i}=\operatorname{Pr}(Y=1)=\left(y^{*} \leq Y\right)=F\left(Y_{i}\right)=\int_{-\infty}^{\beta X_{i}} f(z) d z
$$

where $f(z)$ represents density function, $z$ is normally distributed with 0 mean and unit variance and $P_{i}$ is the probability that a person will participate in the labour market. 


\section{Data, Construction and Description of Variables}

The micro data for four provinces of Pakistan came from the nationwide PIHS conducted in 1998-99 by the Federal Bureau of Statistics, Government of Pakistan. The PIHS records information of all the household members and has questions on labour market participation addressed to adults aged 10 years and above, socioeconomic conditions, employment, income, migration, health, fertility behaviour and consumption pattern.

Since this paper has concentrated only on the sample of married women, the sample size of 51,164 women has been reduced to 9427 married women living in the rural areas of Pakistan. Among them 2313 are involved, while 7114 are not engaged in any kind of economic activities.

\section{Measuring Dependent and Independent Variables}

The main objective of the present paper is to analyse the effect of different socioeconomic and demographic factors on the IRWEA. This has been done at the national level. Women's involvement in earning activities is the dependent variable.

- $\quad$ IRWEA $=1$ if a rural married woman is involved in any earning activities, ${ }^{3}$

- IRWEA $=0$ if she is not involved in an earning activities

There may be a number of socioeconomic and demographic factors influencing currently married women residing in rural areas, to decide whether to be involved in economic activities or not. The exogenous factors have been divided into place of residence, women characteristics, household characteristics, husbands' characteristics and economic status of the household. A detailed description of these characteristics is given below:

- Place of residence includes dummy variables for four provinces; Punjab, Sindh, Balochistan and NWFP.

- Women characteristics include women's age and women's education given by dummy variables for different education categories and women migration status.

- Household characteristics include women head, number of children, family system and household size.

\footnotetext{
${ }^{3}$ Section 1-F Part -B of PIHS (1998-99).
} 
- Husbands' characteristics include husband's age, literacy, and a dummy variable if husband belongs to the agricultural sector.

- Economic status of the household includes annual income of the household.

Detailed description of dependent and explanatory variables is given in Appendix Table 1.

\section{Description of Variables}

The summary statistics of the variables appear in Appendix Table 2. Given the age group of $15-90$ years considered in the survey, it is not surprising that the mean age of married women in our sample is about 36 years. It can be seen that about 46 percent of married women in the rural areas of Punjab are involved in earning activities. This percentage declines to 34 percent and 9 percent in Sindh and NWFP respectively. However the probability of women involvement in earning activities in rural Balochistan is only 8 percent. This indicates that the involvement of married women in earning activities is high in rural areas of the Punjab as compared to the other provinces. The tables show that about 74 percent of rural married women, whose husbands belong to the agricultural sector, are involved in earning activities because they found more working opportunities available at farms.

A glance at the number of children in the table shows that 98 percent of rural married women with small children of 0 to 5 years of age are involved in earning activities. Also, the study found that financial constraints increase the probability of women's participation in earning activities.

\section{Estimates of the Probit Model}

A probit model with a maximum likelihood estimation procedure is employed on a set of explanatory variables by using data from the Pakistan Integrated Household Survey (PIHS) 1998-99. Three sets of numbers reported in Table 1 are probability derivatives (i.e. numbers in bold) at the mean of explanatory variables, estimated parameters and their asymptotic tstatistics reported in parentheses. These derivatives measure the change in probability of IRWEA resulting from one unit change in an explanatory variable. For a dummy variable the probability derivative measures the change in the probability of IRWEA when the dummy variable is equal to 1 rather than zero. Since the probit model is nonlinear, the probability derivatives for this model are not constant. It appears that the most important factor affecting rural women involvement in earning activities 
include province of residence, household income, number of children, household size, husband's age and literacy and a variable if husband belongs to the agriculture sector.

The empirical results indicate that married women living in rural areas of the Punjab and Sindh are respectively 16 percent and 21 percent more likely to be involved in the earning activities as compared to those living in rural areas of Balochistan. More rural women are involved in earning activities because they have higher employment opportunities available in the agricultural sector. Besides rural males, rural women also work in order to earn their living. The probit estimates for Punjab and Sindh are positive and statistically significant. However, rural women in NWFP have 2 percent inverse probability of participating in earning activities and the result is statistically significant. This is so because the social constraints are high in rural areas of NWFP and Balochistan and women are not allowed to go outside frequently and take part in earning activities.

The regression coefficient of the age variable reflects that the probability of 1RWEA significantly increases with age. For example, one-year increase in age is expected to increase the likelihood of rural women involvement in the earning activities by about 1 percentage point. This is so because younger women are less likely to take part in earning activities due to low family size and high child bearing age. Negative and significant coefficient of $A G E S E Q$ shows the falling effect of age i.e. rural married women are likely to work less in old age implying a concave age-IRWEA profile.

The results show that women's education is inversely related to their involvement in agricultural activities. However, the results are not statistically significant. There are two main reasons for this result. First is that a large proportion of educated women belong to urban areas. ${ }^{4}$ Second, there are no formal employment opportunities available for educated women in rural areas.

The table shows that migration has a negative but insignificant association with IRWEA. There are two types of competing effects due to women's migration. One type of effect is that rural women generally migrate from one place to another because of marriage. The other type of effect is that married women also migrate in the hope of securing highly paid work.

\footnotetext{
${ }^{4}$ For example, Appendix Table 2 shows that the mean of women with primary education level is only 0.9 percent while those with education level above primary level is only 4 percent.
} 
These two types of effects compensate each other and the overall effect is negative but negligible.

The regression coefficient of NUCLEAR shows that the probability of rural women's involvement in earning activities is negative if they live in a nuclear family. In a nuclear family the pressure of domestic work is high which does not allow married women to participate in economic activities. They have to look after their children and other household chores by themselves. The results show that one additional woman belonging to a nuclear family is likely to reduce the women's involvement in earning activities by about 2 percentage points.

NCHILD has a negative and significant effect on the probability of women taking part in earning activities. The simple explanation for this is that more pressure of household tasks due to the presence of small children in the family may cause women to stay at home. One additional child in the household is likely to reduce IRWEA by 1 percentage point. Women belonging to large families are induced to participate more in earning activities by 0.2 percentage points.

On the other hand married women's involvement in earning activities in rural areas is 10 percent higher in women headed households but the result is statistically insignificant. Generally there are two types of effects if a woman is the head of the household. She is likely to have a good division of women's labour in the household. She allows some energetic and more productive women to go outside and be involved in earning activities to financially support the household and asks other women to perform household chores. That is why the regression coefficient of FHEAD is positive but insignificant.

The results show that the probability of IRWEA is likely to be inversely associated with the literacy level of the husband. Since literate and educated husbands are likely to earn more income, the economic status of the family is high and female involvement in earning activities is therefore low. So women need not be involved in earning activities in order to increase the household income level. Thus the husband's literacy is likely to reduce the probability of rural women's involvement in earning activities by 5 percentage points. Likewise, $H A G E$ is negatively and significantly correlated with women earning work. This implies that women decision making about their earning activities will decline with the increase in the age of the husband. Similarly, rural women have 7 percentage point high probability of participation in earning activities if their husbands belong to the agricultural sector as compared to those women whose husbands are not involved in agriculture related activities. 
An inverse relationship between household economic status and women's involvement in earning activities is generally observed. A rise in household income exerts a downward pressure on IRWEA. The inverse effect of income on IRWEA is strong, but the magnitude of this effect is rather small. For example, if household income increases by 10 million rupees, the probability of IRWEA reduces by about 14 percentage points. This implies that rural women belonging to rich families are less likely to be involved in earning activities. In Pakistan, a majority of women choose to work to financially support their household. There are very few women in Pakistan who work simply for their own satisfaction. Various studies found that female's decision to participate in the labour market is significantly determined by household income and family size.

\footnotetext{
${ }^{5}$ See for example Hafeez and Ahmad (2002); Chaudliry and Khan (1987); Masood (1988); Bilquees and Hamid (1989); Alderman and Chishti (1989); Kozal and Alderman (1990); Hamid (1991); Kazi and Raza (1991).
} 
Amtul Hafeez Gondal 131

Table 1: Estimates of Probit Model for Earning Activities of Currently Married Women in Rural Pakistan (N=9427)

\begin{tabular}{lrrr}
\hline Explanatory Variable & Coefficients & T-statistics & Derivatives \\
\hline INTERCEPT & -1.828 & $(-12.819)^{*}$ & $\mathbf{- 0 . 5 2 3}$ \\
Place of Residence & & & \\
PUNJAB & 0.558 & $(11.082)^{*}$ & $\mathbf{0 . 1 5 9}$ \\
SINDH & 0.761 & $(15.094)^{*}$ & $\mathbf{0 . 2 1 8}$ \\
NWFP & -0.093 & $(-1.592)^{*}$ & $\mathbf{- 0 . 0 2 7}$ \\
Women Characteristics & & & \\
FAGE & 0.056 & $(7.305)^{*}$ & $\mathbf{0 . 0 1 6}$ \\
FAGESEQ & -0.0007 & $(-7.961)^{*}$ & $\mathbf{- 0 . 0 0 0 2}$ \\
PRIMSEC & -0.145 & $(-0.967)$ & $\mathbf{- 0 . 0 4 2}$ \\
HIGHER & -0.258 & $(-1.415)$ & $\mathbf{- 0 . 0 7 4}$ \\
FMIGSTAT & -0.038 & $(-1.111)$ & $\mathbf{- 0 . 0 1 1}$ \\
Household Characteristics & & & \\
NUCLEAR & -0.084 & $(-2.351)^{*}$ & $\mathbf{- 0 . 0 2 4}$ \\
NCHILD & -0.036 & $(-2.238)^{*}$ & $\mathbf{- 0 . 0 1 0}$ \\
FHEAD & 0.364 & $(0.519)$ & $\mathbf{0 . 1 0 4}$ \\
FSIZE & 0.008 & $(1.639)^{*}$ & $\mathbf{0 . 0 0 2}$ \\
Husband Characteristics & & & \\
HUSLITRCY & -0.199 & $(-6.128)^{*}$ & $\mathbf{- 0 . 0 5 7}$ \\
HUSAGE & -0.005 & $(-2.045)^{*}$ & $\mathbf{- 0 . 0 0 1}$ \\
AGRI & 0.254 & $(7.343)^{*}$ & $\mathbf{0 . 0 7 3}$ \\
Economic Status of The Household & & \\
HHINCOME & -0.00005 & $(-9.723)^{*}$ & $\mathbf{- . 0 0 0 0 0 1 4}$ \\
N & 9427 & & \\
Log Likelihood & -4761.70 & & \\
R2 & 0.108 & & \\
\hline
\end{tabular}

Note: The dependent variable is set equal to one for females who are involved in economic activities and zero otherwise. The statistics significant at $5 \%$ and $10 \%$ levels are indicated by $*$ and $* *$ respectively.

\section{Conclusion and Policy Implications}

This paper has indicated that there is a set of factors which influences the involvement of married women in economic activities in Pakistan. Married women living in rural areas of Sindh and the Punjab are more involved whereas those living in rural Balochistan and NWFP are less 
likely to be involved in economic activities. It has been found that younger women are less likely to be involved in economic activities. The probability of women involvement in earning activities also declines with the migration of married women from one place to another. Similarly NUCLEAR and $N C H I L D$ have a strong negative association with IRWEA. Husbands' literacy level, husbands' age and household annual income have a strong negative relationship with IRWEA. However FSIZE has a positive and significant effect on it. Likewise married women in Pakistan are more engaged in economic activities if their husbands are involved in the agricultural sector.

These conclusions have important economic and policy implications. Involvement of married women in economic activities is reasonably high in the rural areas of Pakistan. Weak financial background and large family size are the major reasons for this high participation whereas small number of children, nuclear family set up and husbands' literacy levels are likely to hinder the IRWEA.

To address these issues, there is a need for policy on women's employment to be carefully planned, based on proper analyses of available Pakistan Integrated Household Survey data that provides the most important insights in this respect. The government can also intervene in the labour market with measures to create better working conditions and increasing earning opportunities for rural women, particularly in the agricultural sector. The government should also ensure the provision of family planning and childcare facilities. 


\section{Appendix}

Table 1. Definition of Variables

\begin{tabular}{|c|c|}
\hline Variables & Description \\
\hline \multicolumn{2}{|c|}{ Dependent Variables } \\
\hline IRWEA & $\begin{array}{l}=1 \text { if a rural woman is involved in economic } \\
\text { activities }\end{array}$ \\
\hline IRWEA & $=0$ if she is not involved in economic activities \\
\hline \multicolumn{2}{|c|}{ Explanatory Variables } \\
\hline \multicolumn{2}{|c|}{ Place of Residence } \\
\hline PUNJAB & $\begin{array}{l}=1 \text {, if woman is currently residing in the rural areas } \\
\text { of province Punjab, and } 0 \text { otherwise. }\end{array}$ \\
\hline SINDH & $\begin{array}{l}=1 \text {, if woman is currently residing in the rural areas } \\
\text { of province Sindh, and } 0 \text { otherwise. }\end{array}$ \\
\hline NWFP & $\begin{array}{l}=1 \text {, if woman is currently residing in the rural areas } \\
\text { of province NWFP, and } 0 \text { otherwise. }\end{array}$ \\
\hline BALOCHISTAN & $\begin{array}{l}=1 \text {, if woman is currently residing in the rural areas } \\
\text { of province Balochistan, and } 0 \text { otherwise. }\end{array}$ \\
\hline \multicolumn{2}{|c|}{ Women Characteristics } \\
\hline FAGE & Woman's age \\
\hline FAGESEQ & Age*Age \\
\hline ILLITERATE & $\begin{array}{l}=1 \text { if the woman has not acquired formal education } \\
\text { and } 0 \text { otherwise. }\end{array}$ \\
\hline PRIMSEC & $\begin{array}{l}=1 \text { if woman has primary or secondary education, } 0 \\
\text { otherwise }\end{array}$ \\
\hline HIGHER & $\begin{array}{l}=1 \text { if woman has intermediate or degree level } \\
\text { education, } 0 \text { otherwise }\end{array}$ \\
\hline FMIGSTAT & $=1$ if woman is migrant, 0 otherwise \\
\hline \multicolumn{2}{|c|}{ Household Characteristics } \\
\hline NUCLEAR & $=1$ if woman lives in nuclear family, 0 otherwise \\
\hline NCHILD & Number of children \\
\hline FHEAD & $=1$ if woman is head of the household, 0 otherwise \\
\hline FSIZE & Family size \\
\hline \multicolumn{2}{|c|}{ Husband's Characteristics } \\
\hline HUSLITRCY & $=1$ if husband is literate, 0 otherwise \\
\hline HUSAGE & Husbands' age \\
\hline$A G R I$ & $=1$ if husband belongs to agriculture, 0 otherwise \\
\hline \multicolumn{2}{|c|}{ Economic Status of The Household } \\
\hline HHINCOME & Household annual income \\
\hline$N$ & Sample size \\
\hline
\end{tabular}


134 The Lahore Journal of Economics, Vol.8, No.2

TABLE 2: Summary Statistics of Selected Sample for Rural Pakistan (N=9428) (Sample Means and Standard Deviations)

\begin{tabular}{|c|c|c|}
\hline Explanatory Variables & IRWEA1 & IRWEAO \\
\hline \multicolumn{3}{|l|}{ Place of Residence } \\
\hline PUNJAB & 0.467 & 0.367 \\
\hline \multirow[t]{2}{*}{ SINDH } & $\begin{array}{r}(0.499) \\
0.349\end{array}$ & $\begin{array}{r}(0.482) \\
0.216\end{array}$ \\
\hline & $\begin{array}{c}(0.477) \\
0.093\end{array}$ & $\begin{array}{c}(0.411) \\
0.223\end{array}$ \\
\hline$N W F P$ & $(0.291)$ & $(0.416)$ \\
\hline \multirow[t]{2}{*}{ BALOCHISTAN } & 0.085 & 0.194 \\
\hline & $0.279)$ & $(0.395)$ \\
\hline \multicolumn{3}{|l|}{ Women Characteristics } \\
\hline$F A G E$ & $\begin{array}{r}36.855 \\
(11.773)\end{array}$ & $\begin{array}{r}37.879 \\
(13.449)\end{array}$ \\
\hline \multirow[t]{2}{*}{ FAGESEQ } & 1496.853 & 1615.743 \\
\hline & $\begin{array}{r}(960.399) \\
0.009\end{array}$ & $\begin{array}{r}(1147.112) \\
0.011\end{array}$ \\
\hline PRIMSEC & $(0.093)$ & $(0.103)$ \\
\hline HIGHER & 0.004 & 0.100 \\
\hline \multirow[t]{2}{*}{ FMIGSTAT } & $\begin{array}{r}(0.066) \\
0.316\end{array}$ & $\begin{array}{r}(0.099) \\
0.299\end{array}$ \\
\hline & $(0.465)$ & $(0.458)$ \\
\hline \multicolumn{3}{|c|}{ Household Characteristics } \\
\hline NUCLEAR & $\begin{array}{r}0.526 \\
(0.499)\end{array}$ & $\begin{array}{r}0.512 \\
(0.590)\end{array}$ \\
\hline NCHILD & 1.032 & 1.026 \\
\hline FHEAD & $\begin{array}{l}(1.065) \\
0.0004\end{array}$ & $\begin{array}{l}(1.126) \\
0.0005\end{array}$ \\
\hline \multirow[b]{2}{*}{ Wh h d' Chontorit } & $\begin{array}{r}(0.021) \\
7.650 \\
(3.639)\end{array}$ & $\begin{array}{r}(0.024) \\
8.006 \\
(4.487)\end{array}$ \\
\hline & \multicolumn{2}{|c|}{ Husband's Characteristics } \\
\hline HUSLITRCY & $\begin{array}{r}0.351 \\
(0.478)\end{array}$ & $\begin{array}{r}0.447 \\
(0.497)\end{array}$ \\
\hline HUSAGE & 42.483 & 44.003 \\
\hline \multirow[t]{2}{*}{$A G R I$} & $\begin{array}{r}(13.415) \\
0.745\end{array}$ & $\begin{array}{r}(14.851) \\
0.548\end{array}$ \\
\hline \multirow{2}{*}{\multicolumn{3}{|c|}{ Economic Status of the Household }} \\
\hline & & \\
\hline HHINCOME & $\begin{array}{r}3231.580 \\
(4801.337) \\
2313\end{array}$ & $\begin{array}{r}38101.455 \\
(47081.757) \\
7114\end{array}$ \\
\hline
\end{tabular}

Notes: numbers in parenthesis are standard deviations. 
Amtul Hafeez Gondal 135

\section{References}

Ahmad, Munir, Chand Asghar, and Nasir Alam Khan. 1993. 'Participation of Rural Women in Agricultural and Household Activities: A Micro-leve1 Analysis. In A. S. Haider, Z. Hussain, R. McConnen, and S. J. Malik (ed.) Agriculture Strategies in the 1990s: Issues and Policies. Islamabad: Pakistan Association of Agricultural Social Scientists.

Alderman, H. and S. Chishti 1989. 'Simultaneous Determination of Household and Market Oriented Activities of Women in Rural Pakistan', Research in Population Economics. Volume 17.

Bilqees, F and S. Hamid 1989. 'Lack of Education and Employment Patterns of Poor Urban Women in Rawalpindi City', The Pakistan Development Review. 30:4.

Chaudary, G. And Khan, Z. 1987. 'Female Labour Force Participation Rate in Rural Pakistan: Some Fundamental Explanations and Policy Implications', The Pakistan Development Review, 26:4.

- 1998. Pakistan Integrated Household Survey, 1998-99. Federal Bureau of statistics. Statistics Division, Islamabad.

Hafeez, A. and Eatzaz Ahmed, 2002. 'Factors Affecting Labour Force Participation Decision of Educated Married Women in a Punjabi District', Sustainable Development Policy Institute, Islamabad No. 74, 2-12.

Hamid, Shahnaz. 1991. 'Determinants of the Supply of Women in the Labour Market: A Micro Analysis'.. The Pakistan Development Review. 30:4.

Human Development in South Asia 2000: The Gender Question, Oxford University Press.

Jamil, K. 2001. 'The Determinants of Women Labour Force Participation in Pakistan', M.Phil Dissertation, submitted to the Department of Economics, Quaid-e-Azam University, Islamabad.

Kazi, S. and B. Raza 1991. 'Duality of Female Employment In Pakistan', The Pakistan Development Review, 30:4. 
136 The Lahore Journal of Economics, Vol.8, No.2

Khan, S. A. and F. Bilquees. 1976. 'The Attitude, Environment and Activities of Rural Economy: Study of Jhok Sayal', Pakistan Institute of Development Economics Research Report No. 98. Islamabad.

Koze1, Valeric and Harold Alderman 1990. 'Factors Determining Work Participation and Labour Supply Decisions in Pakistan's Urban Areas', The Pakistan Development Review. Volume 29, 11-18.

Masood, F. 1988. 'Women in Traditional Irrigated Farming System', In Rural Women in Pakistan's Farming System's Research. Pakistan Agricultural Research Council. Islamabad.

Sarwar, M. and M. A. Saleem 1993. 'Baseline Study of Punjab Small Holders Dairy Development Project in Gujranwala', Punjab Economic Research Institute. Lahore.

Tassawar, S. I. 1993. 'The Cultural Context of Women's Productive Invisibility: A Case Study of a Pakistani Village', The Pakistan Development Review, 32:1. 